\title{
AN IMMUNOCHEMICAL STUDY OF THE PROTEINS IN CEREBROSPINAL FLUID
}

\author{
F. D. ROSENTHAL AND J. F. SOOTHILL \\ From the Queen Elizabeth Hospital, and Department of Experimental \\ Pathology, University of Birmingham
}

Quantitative gel diffusion precipitin techniques make possible rapid estimation of a wide range of serum proteins. We report a study of cerebrospinal fluid proteins using such a technique. The cerebrospinal fluid: serum concentration ratios for seven serum proteins were determined in patients investigated for a wide range of neurological disease.

\section{METHODS}

Cerebrospinal fluid was obtained by lumbar puncture. Only fluids containing fewer than 100 red blood cells/ c.mm. were studied.

The cerebrospinal fluid protein was concentrated by the technique of Grant (1957), in most cases to between 500 and $1,000 \mathrm{mg} . / 100 \mathrm{ml}$. Cerebrospinal fluids with protein concentrations already in this range were not further concentrated.

The details of the immunochemical gel diffusion precipitin technique used are described by Soothill (1962). It is an adaptation of the method of Gell (1957). Proteins studied were albumin, siderophilin, $\gamma$ globulin, high molecular weight $\alpha_{2}$ glycoprotein, $\beta$ lipoprotein (arranged in order of molecular weight in Table I), and, in a few instances, caeruloplasmin and a component of complement.

The method entails visual matching of patterns of precipitate produced by suitable dilutions of cerebrospinal fluid and of serum, when they react with a standard series of dilutions of specific antiserum. Direct readings of the concentration ratios are obtained (after multiplication by the concentration factor). The error of the method, which entails a constant coefficient of variation for each protein over a wide range of concentrations, has been described in detail by Soothill (1962). It varies with different proteins, but the coefficient of variation of the estimation is about $18 \%$ (see Table I).

Reactions of identity were demonstrated by the technique of Ouchterlony (1948). Immunoelectro- phoresis was performed by a modification of the technique of Grabar and Williams (1953).

A rabbit was immunized to cerebrospinal fluid protein, concentrated to $1 \mathrm{~g}$./100 ml., using a Freund's adjuvant preparation subcutaneously and a saline solution intravenously, by the immunization course described by Soothill (1962). The antiserum (six volumes) was absorbed with one volume of human serum, with incubation at $37^{\circ} \mathrm{C}$. for two hours and at $4^{\circ} \mathrm{C}$. for 16 hours, after which the precipitate was removed by centrifugation.

\section{RESULTS}

The results are shown in Table II. The cerebrospinal fluid/serum concentration ratios for albumin are given directly, and each ratio for the globulins is expressed as a percentage of the albumin ratio. The patients are divided into six diagnostic groups: (1) No demonstrable organic neurological disease; (2) idiopathic and post-traumatic epilepsy; (3) disseminated sclerosis; (4) cerebrospinal fluid block; (5) peripheral neuropathy of Guillain-Barré type; and (6) miscellaneous. The average results for groups 1 to 5 are plotted in Fig. 1.

These show that the proteins studied were present in the cerebrospinal fluid in concentrations such that there was a selectivity in favour of proteins of smaller molecular weight. However, in all groups, except those with a very high cerebrospinal fluid protein concentration, the siderophilin was present in concentrations as high as or higher than the albumin, and, in cases of disseminated sclerosis, the $\gamma$ globulin often exceeded the albumin. $\beta$ lipoprotein was detected in the cerebrospinal fluid of some patients in all groups except the first. The results suggest that the failure to detect it in the majority of specimens was due to the limitation of volume of

\section{TABLE I}

ACCEPTED VALUES FOR MOLECULAR WEIGHTS OF PROTEINS AND COEFFICIENTS OF VARIATION OF THE ESTIMATION FOR EACH

\begin{tabular}{|c|c|c|c|c|c|c|}
\hline Protein & Albumin & Siderophilin & $\gamma$ Globulin & Caeruloplasmin & $\alpha_{2}$ Glycoprotein & BLipoprotein \\
\hline Molecular weight & 68,000 & 90,000 & 150,000 & 150,000 & 840,000 & $1-3,000,000$ \\
\hline Coefficient of variation $(\%)$ & 19 & 19 & 13 & 15 & 25 & 18 \\
\hline
\end{tabular}


TABLE II

RESULTS OF C.S.F./SERUM CONCENTRATION RATIOS FOR SEVEN SERUM PROTEINS IN 50 PATIENTS

No. Age Sex Diagnosis
Concen- C.S.F./Serum Concentration Ratios for

tration

Albumin Globulins as Percentage of Albumin

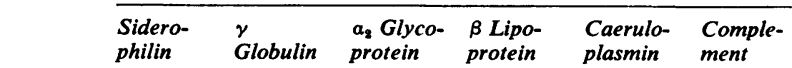

$$
\text { Factor }
$$

Group 1 No demonstrable neurological disease

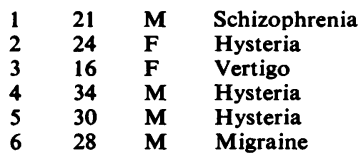

Group 2 Idiopathic and post-traumatic epilepsy

$\begin{array}{rlll}7 & 29 & \text { F } & \text { Idiopathic epilepsy } \\ 8 & 38 & \text { M } & \text { Post-traumatic epilepsy } \\ 9 & 18 & \text { F } & \text { Post-traumatic epilepsy } \\ 10 & 47 & \text { M } & \text { Post-traumatic epilepsy } \\ 11 & 56 & \text { M } & \text { Post-traumatic epilepsy } \\ 12 & 29 & \text { F } & \text { Birth injury epilepsy }\end{array}$

$\begin{array}{rll}100 & 1 / 300 & 150 \\ 28 & 1 / 675 & 240 \\ 70 & 1 / 550 & 266 \\ 60 & 1 / 80 & 100 \\ 23 & 1 / 550 & 100 \\ 46 & 1 / 640 & 100\end{array}$

50
50
67
33
37
50

19
75
33
17
25
22

$\begin{array}{rr}\overline{11}^{1} & 150 \\ - & 50 \\ - & 37 \\ - & -\end{array}$

\section{-
-
87
35}

Group 3 Disseminated sclerosis

$\begin{array}{llll}13 & 55 & \text { F } & \text { Disseminated sclerosis } \\ 14 & 36 & \text { M } & \text { Disseminated sclerosis } \\ 15 & 40 & \text { F } & \text { Disseminated sclerosis } \\ 16 & 49 & \text { F } & \text { Disseminated sclerosis } \\ 17 & 37 & \text { M } & \text { Disseminated sclerosis } \\ 18 & 22 & \text { F } & \text { Disseminated sclerosis } \\ 19 & \text { 51 } & \text { F } & \text { Disseminated sclerosis } \\ 20 & 54 & \text { M } & \text { Disseminated sclerosis }\end{array}$

$\begin{array}{lll}45 & 1 / 270 & 160 \\ 30 & 1 / 240 & 160 \\ 27 & 1 / 650 & 200 \\ 46 & 1 / 360 & 200 \\ 68 & 1 / 280 & 200 \\ 48 & 1 / 400 & 160\end{array}$

$\begin{array}{ll}17 & 33 \\ 57 & 33 \\ 60 & 50 \\ 33 & 50 \\ 33 & 25 \\ 66 & 33\end{array}$

$\begin{array}{rrr}<6 & - & - \\ 2 & 114 & - \\ - & 87 & - \\ -3 & 114 & - \\ <6 & 40 & 25 \\ & 66 & -\end{array}$

Group 4 Peripheral neuropathy

21
22
23
24
25
26
27
28
29

$\begin{array}{ll}\text { M } & \text { Peripheral neuropathy } \\ \text { M } & \text { Peripheral neuropathy } \\ \text { F } & \text { Peripheral neuropathy } \\ \text { F } & \text { Peripheral neuropathy } \\ \text { M } & \text { Peripheral neuropathy } \\ \text { M } & \text { Peripheral neuropathy } \\ \text { F } & \text { Peripheral neuropathy } \\ \text { M } & \text { Peripheral neuropathy } \\ \text { M } & \text { Peripheral neuropathy (atypical) }\end{array}$

$\begin{array}{clr}4 & 1 / 16 & 66 \\ 27 & 1 / 150 & 100 \\ 1 & 1 / 8 & 50 \\ 6 & 1 / 30 & 100 \\ 5 \frac{1}{2} & 1 / 100 & 160 \\ 4 & 1 / 32 & 100 \\ 3 & 1 / 40 & 117 \\ 3 & 1 / 36 & 60 \\ 1 & 1 / 7 & 117\end{array}$

75
100
133
200
100
170
64
87

15
10
33
17
18
37
13
29

$\begin{array}{rrr}<2 & 37 & - \\ - & - & - \\ - & 50 & - \\ - & 100 & - \\ - & - & - \\ - & - & -\end{array}$

Group 5 Block to flow of C.S.F.

$\begin{array}{llll}30 & 20 & \text { M } & \begin{array}{l}\text { Aqueduct stenosis } \\ 31\end{array} \\ 32 & 50 & \text { M } & \text { Cervical spondylosis } \\ \text { Spinal meningioma }\end{array}$

$\begin{array}{llr}12 & 1 / 32 & 66 \\ 18 & 1 / 125 & 117 \\ 10 & 1 / 140 & 100\end{array}$

Group 6 Miscellaneous

\begin{tabular}{|c|c|c|c|c|c|c|c|c|c|c|c|}
\hline 33 & 52 & $\mathbf{M}$ & Cerebral atrophy? arteriosclerosis & 120 & $1 / 480$ & 200 & 50 & 50 & 4 & - & - \\
\hline 34 & 47 & $\mathbf{M}$ & Cerebral atrophy? alcoholic & 150 & $1 / 750$ & 167 & 62 & 31 & $<5$ & 167 & - \\
\hline 35 & 65 & $\mathbf{F}$ & Cerebral atrophy ? familial & 150 & $1 / 450$ & 300 & 37 & 60 & $<10$ & 75 & - \\
\hline 36 & 32 & $\mathbf{M}$ & Leber's optic atrophy & 24 & $1 / 240$ & 167 & 21 & 31 & $<4$ & 83 & 62 \\
\hline 37 & 56 & $\mathbf{M}$ & Chiasmal lesion ? cause & 55 & $1 / 165$ & 150 & 75 & 37 & 1 & 100 & - \\
\hline 38 & 60 & $\mathbf{F}$ & Arteriosclerosis & 40 & $1 / 480$ & 200 & 41 & 31 & $<2$ & 41 & - \\
\hline 39 & 57 & $\mathbf{M}$ & Cerebral atrophy & 186 & $1 / 560$ & 200 & 50 & 37 & 10 & 75 & - \\
\hline 40 & 21 & $\mathbf{M}$ & Cerebral atrophy following & & & & & & & & \\
\hline & & & cerebral abscess & 25 & $1 / 200$ & 200 & 40 & 13 & $<1$ & 67 & - \\
\hline 41 & 49 & $\mathbf{F}$ & Syringomyelia & 36 & $1 / 210$ & 160 & 57 & 33 & - & 75 & - \\
\hline 42 & 42 & $\mathbf{F}$ & Left hemiparesis ? cause & 39 & $1 / 240$ & 100 & 50 & 25 & $<0.5$ & 50 & - \\
\hline 43 & 61 & $\mathbf{F}$ & Hemiplegia ? cause & 47 & $1 / 150$ & 150 & 50 & 37 & 2 & 60 & - \\
\hline 44 & 48 & $\mathbf{F}$ & Cerebral atrophy ? cause & 31 & $1 / 180$ & 117 & 30 & 25 & 1 & 50 & - \\
\hline 45 & 50 & $\mathbf{M}$ & Motor neurone disease & 35 & $1 / 175$ & 200 & 50 & 31 & 2 & - & - \\
\hline 46 & 56 & $\mathbf{M}$ & Midbrain vascular syndrome & 55 & $1 / 330$ & 100 & 30 & 25 & - & - & 75 \\
\hline 47 & 44 & $\mathbf{F}$ & Hemiplegia vascular & 45 & $1 / 450$ & 167 & 41 & 21 & - & - & - \\
\hline 48 & 54 & $\mathbf{F}$ & Congenital tremor & 42 & $1 / 300$ & 200 & 58 & 29 & - & - & 35 \\
\hline 49 & 62 & $\mathbf{M}$ & Depression C.S.F. protein high & 38 & $1 / 190$ & 143 & 36 & 16 & $1 \cdot 5$ & - & - \\
\hline 50 & 30 & $\mathbf{M}$ & Migraine C.S.F. protein high & 26 & $1 / 200$ & 133 & 50 & 14 & - & 67 & - \\
\hline
\end{tabular}

(-) indicates that analysis was not performed owing to insufficient C.S.F. 


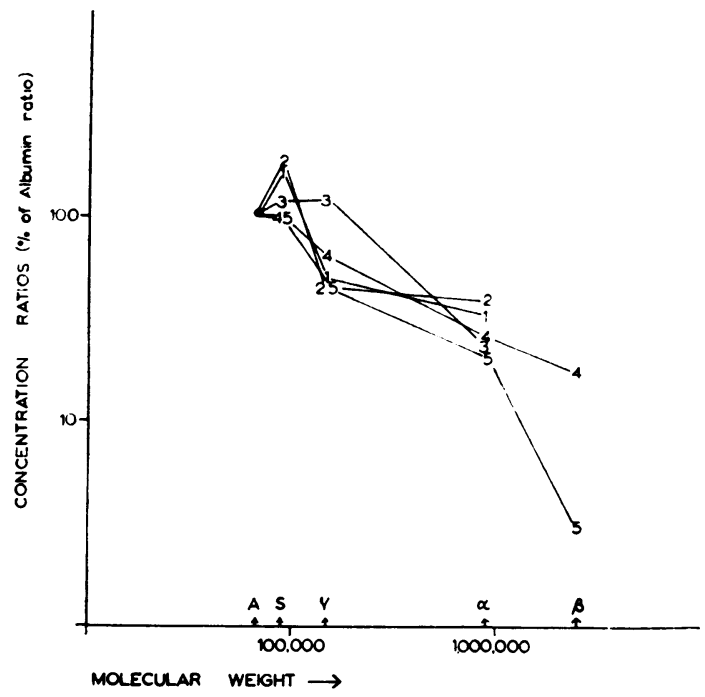

FIG. 1. Average values for each of the first five groups of patients of concentration ratios of five of the proteins (expressed as a percentage of albumin) plotted against the molecular weight of the protein (log-log scale). Molecular weight of each protein is given on abscissa axis: $A=$ albumin: $S=$ siderophilin; $\gamma=\gamma$ globulin; $\alpha=$ high molecular weight $a_{2}$ glycoprotein; and $\beta=\beta$ lipoprotein. Numbers of the groups, as given in Table II, are used as symbols for marking the points on the graph.

cerebrospinal fluid available so that the degree of concentration was insufficient for it to be detectable. In no instance was it demonstrated to be less than $0.5 \%$ of the albumin. It was relatively raised in the cerebrospinal fluid of patients with peripheral neuropathy, who had a very high total cerebrospinal fluid protein concentration, and in two of the three patients with cerebrospinal fluid block, in whom the cerebrospinal fluid protein was only slightly raised. Ratios for caeruloplasmin were rather variable. In one patient with Wilson's disease, in whom the serum concentration of caeruloplasmin was $16 \%$ of that of a standard serum from a healthy adult male, only trace quantities were detected in the cerebrospinal fluid. The ratios for the component of complement were also rather variable, but there was no evidence of deficiency in the one case of disseminated sclerosis studied.

To exclude the possibility that the excess of siderophilin in the cerebrospinal fluid might be an artifact of the concentration technique, the cerebrospinal fluid/serum concentration ratios for albumin, siderophilin, and $\gamma$ globulin were estimated for three patients, using unconcentrated cerebrospinal fluid. The results, which are given in Table III, confirm that siderophilin was present in cerebrospinal fluid at a higher relative concentration than albumin.

\section{TABLE II I}

CEREBROSPINAL FLUID/SERUM CONCENTRATION RATIOS OF THREE SERUM PROTEINS FOR THREE PATIENTS OBTAINED USING UNCONCENTRATED CEREBROSPINAL FLUID

Diagnosis C.S.F./Serum Concentration Ratios

\begin{tabular}{lccc} 
& Albumin & Siderophilin & $\gamma$ globulin \\
\cline { 2 - 4 } & $1 / 160$ & $1 / 64$ & $1 / 256$ \\
Motor neurone disease & $1 / 160$ & $1 / 56$ & $1 / 320$ \\
Paralysis agitans & $1 / 112$ & $1 / 96$ & $1 / 160$
\end{tabular}

Reactions of identity were obtained for albumin, siderophilin, $\gamma$ globulin, and $\alpha_{2}$ glycoprotein between

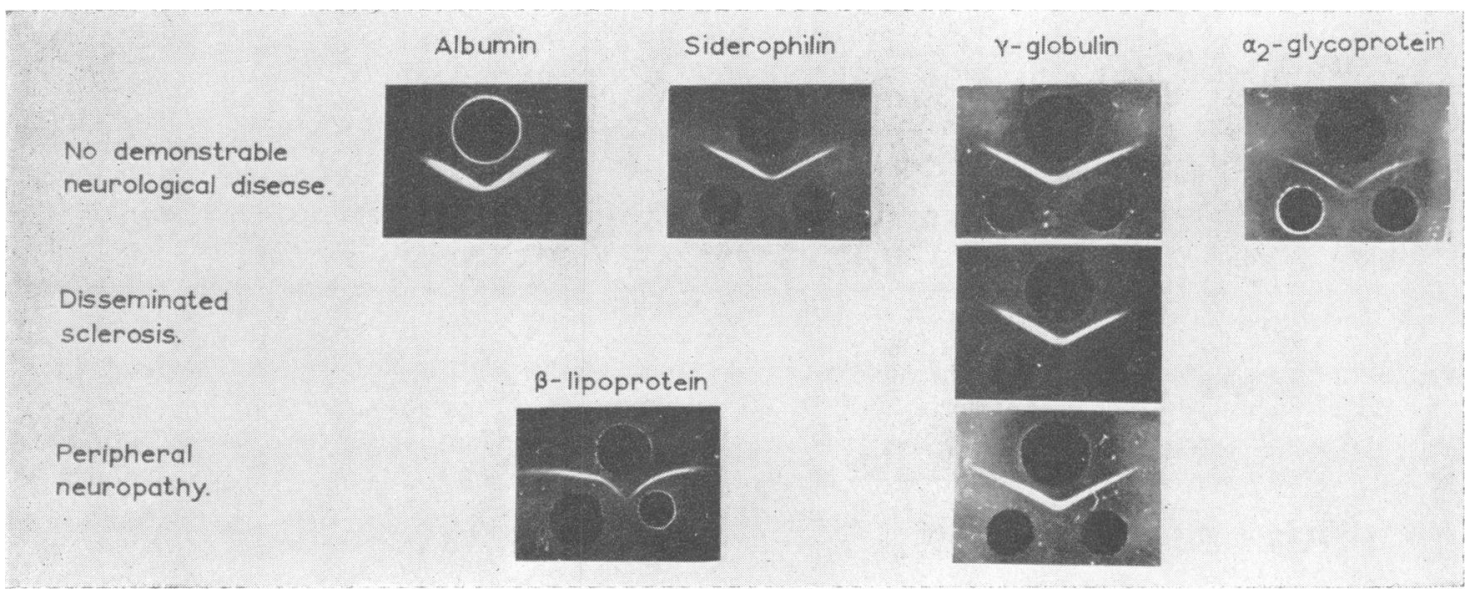

FIG. 2. Reactions of identity between serum (left) and concentrated cerebrospinal fluid protein (right) for five serum proteins. 
cerebrospinal fluid and serum from two of the patients with no demonstrable neurological disease, for $\gamma$ globulin from the case of disseminated sclerosis, and for $\gamma$ globulin and $\beta$ lipoprotein from the case of peripheral neuropathy. These are shown in Fig. 2 .

The rabbit antiserum against concentrated cerebrospinal fluid protein, when reacted against normal human serum and concentrated cerebrospinal fluid by immunoelectrophoresis, gave a number of precipitin lines including albumin, $\gamma$ globulin, and several $\alpha$ and $\beta$ globulins. After absorption with human serum, this antiserum gave no precipitation either with human serum or with concentrated cerebrospinal fluid. Thus no antibodies were obtained to proteins which were in cerebrospinal fluid but were not present in the serum.

\section{DISCUSSION}

Immunoelectrophoretic study of cerebrospinal fluid proteins has demonstrated many plasma proteins in the cerebrospinal fluid in health and disease (Frick, 1959; Burtin, 1960). Quantitative estimations of albumin and $\gamma$ globulin have been reported by various techniques, including the very precise immunochemical study of Kabat, Glusman, and Knaub (1948) who demonstrated that, in the normal cerebrospinal fluid, albumin is present in a higher concentration than $\gamma$ globulin relative to serum, suggesting selective ultrafiltration from serum, favouring the smaller molecule. Reports that $\beta$ lipoprotein, the largest serum protein, is absent from cerebrospinal fluid (Baudouin, Lewin, and Hillion, 1953; Burtin, 1960) are in keeping with this concept, but quantitative data of other proteins are required to confirm this hypothesis, and to confirm the observation made by immunoelectrophoresis (Gavrilesco, Courcon, Hillion, Uriel, Lewin, and Grabar, 1955; Burtin, 1960) that siderophilin is in relatively high concentration in cerebrospinal fluid.

Our results on cerebrospinal fluid from patients with no demonstrable neurological disease confirm such a selectivity for albumin, $\gamma$ globulin, $\alpha_{2}$ glycoprotein, and $\beta$ lipoprotein, and the reported relative excess of siderophilin.

It seems unlikely that siderophilin would be made within the central nervous system, but it is possible that the return of proteins to the serum may also be selective. Available isotope data (Frick and ScheidSeydel, 1958a) suggest that albumin is not broken down in the cerebrospinal fluid so that the excess of siderophilin is unlikely to be due to relatively slow destruction.

Selectivity, according to molecular size, suggests filtration through a semi-permeable membrane, but it is difficult to see where such a structure would lie unless the proteins pass through the intact ependymal cells. If this is so, it is conceivable that there could be active concentration of siderophilin in a way similar to the active concentration of chloride but such a process for a protein would be unique.

A similar selectivity was demonstrated in all pathological cerebrospinal fluids studied, except for the excess of $\gamma$ globulin in the cerebrospinal fluid of cases of disseminated sclerosis previously reported by Kabat et al. (1948). (We studied no patients with neurosyphilis in whom high cerebrospinal fluid $\gamma$ globulin has also been reported.) Frick and ScheidSeydel (1958b) have reported evidence that this is due to formation of $\gamma$ globulin within the central nervous system. There was no evidence of deficiency of the component of complement in the cerebrospinal fluid in the one case of disseminated sclerosis which we studied for this protein; this might have arisen if the $\gamma$ globulin were being involved in an antigen-antibody reaction in the cerebrospinal fluid.

Siderophilin was present in excess in all the groups of patients, except those with peripheral neuropathy with a very high cerebrospinal fluid protein concentration, and one case with block to cerebrospinal fluid flow.

$\beta$ lipoprotein was present in considerable concentration in the cerebrospinal fluid of the patients with peripheral neuropathy, though it was still the protein present in the least relative concentration. Certain cerebrospinal fluids in all the other diagnostic groups except the first contained $\beta$ lipoprotein, which is contrary to the reports of Baudouin et al. (1953) and Burtin (1960). Our data suggest that, if the volume of cerebrospinal fluid is sufficient to allow adequate concentration, $\beta$ lipoprotein might well be found.

Our data are insufficient for an assessment of the diagnostic value of these tests, but the speed and ease of the determination make them practicable for routine use. It seems likely that the albumin $/ \gamma$ globulin concentration ratio would be of value in the diagnosis of patients in whom disseminated sclerosis is suspected, and this can be determined on unconcentrated cerebrospinal fluid; this application will be studied further. The various empirical diagnostic tests on cerebrospinal fluid, such as the Lange curve, probably depend on the relative concentrations of various proteins, just as the empirical tests of liver function depend on the elevation of $\gamma$ globulin concentration and depression of the $\beta$ lipoprotein concentration. It is probable that direct measurement of the concentration of the relevant proteins in cerebrospinal fluid would be a more satisfactory diagnostic procedure.

The reactions of identity for albumin, sidero- 
philin, and $\gamma$ globulin in normal cerebrospinal fluids, and for $\gamma$ globulin in that from the case of disseminated sclerosis confirm the results of Frick and Scheid-Seydel (1957) that, within the limits of this technique, these proteins, when in the cerebrospinal fluid, are identical with those in the serum. Reactions of identity were also demonstrated for $\alpha_{2}$ glycoprotein in normal cerebrospinal fluid and for $\gamma$ globulin and $\beta$ lipoprotein in the cerebrospinal fluid from the cases of peripheral neuropathy. The failure to obtain antibodies to non-serum proteins when a rabbit was immunized with concentrated cerebrospinal fluid protein suggests, though it does not prove, that the protein of cerebrospinal fluid is entirely, or almost entirely, composed of serum proteins.

\section{SUMMARY}

Quantitative immunochemical analyses of seven serum proteins in cerebrospinal fluid from patients with a wide range of neurological abnormalities demonstrated an overall tendency to selection of the smaller molecules.

Exceptions were the excess of siderophilin in all fluids studied and the excess of $\gamma$ globulin in patients with disseminated sclerosis, as has been previously reported. $\beta$ lipoprotein was present in the cerebrospinal fluid of patients with peripheral neuropathy with high cerebrospinal fluid protein concentration and in several other individuals.

No evidence was obtained of non-serum cerebrospinal fluid protein.

The possible clinical value of this procedure is suggested.

We are grateful to Dr. G. S. Hall, Dr. J. M. Jefferson, and Dr. M. Sim for permission to study patients under their care, and to Professor J. R. Squire for advice and help.

\section{REFERENCES}

Baudouin, A., Lewin, J., and Hillion, P. (1953). C.R. Soc. Biol. (Paris), $147,1036$.

Burtin, P. (1960). In Analyse Immuno-Électrophorétique, Grabar, P. and Burtin, P. Masson, Paris.

Frick, E. (1959). Klin. Wschr., 37, 645.

-_, and Scheid-Seydel, L. (1957). Z. ges. exp. Med., 129, 221. (1958a). Klin. Wschr., 36, 66. (1958b). Ibid., 36, 857 .

Gavrilesco, K., Courcon, J., Hillion, P., Uriel, J., Lewin, J., and Grabar, P. (1955). Bull. Soc. Chim. biol. (Paris), 37, 803.

Gell, P. G. H. (1957). J. clin. Path., 10, 67.

Grabar, P., and Williams, C. A. (1953). Biochim. Biophys. Acta, 10, 193.

Grant, G. H. (1957). J. clin. Path., 10, 360.

Kabat, E. A., Glusman, M., and Knaub, V. (1948). Amer. J. Med., 4, 653.

Ouchterlony, O. (1948). Acta path. microbiol. scand., 25, 186. Soothill, J. F. (1962). J. Lab. clin. Med. In press. 